\title{
REAKSI SAHAM PERBANKAN TERHADAP PENURUNAN BI RATE APRIL 2016 DAN IMPLIKASINYA TERHADAP STRATEGI INVESTASI: PENGUJIAN TERHADAP HIPOTESIS PASAR EFISIEN
}

\author{
BANKING SHARES REACTION TO THE BI RATE DEGRADATION \\ IN APRIL 2016 AND ITS IMPLICATION TO INVESTMENT \\ STRATEGY: TESTING OF EFFICIENT MARKET HYPOTHESIS
}

\author{
N. Triaryati \\ NMW. Kusumadewi \\ Fakultas Ekonomi Universitas Udayana Bali \\ Email: triaryati@unud.ac.id
}

\begin{abstract}
ABSTRAK
Stagnasi suku bunga BI pada tahun 2015 berada pada tingkat 7.5\%, menyebabkan perlambatan pertumbuhan laba dan harga saham di sektor perbankan. Pengumuman kebijakan tingkat suku bunga BI dan BI 7-Day Repo pada tanggal 21 April 2016 merupakan informasi baru yang relevan untuk sektor perbankan di Indonesia, karena keduanya merupakan acuan suku bunga untuk menentukan suku bunga deposito dan dasar penggunaan suku bunga, yang berhubungan langsung dengan keuntungan dan pengeluaran sektor perbankan.

Studi ini memverifikasi adanya abnormal return selama pengumuman, untuk mengetahui kemampuan pasar untuk secara langsung menyerap informasi yang relevan dan tercermin dalam harga saham sektor perbankan. Prosedur yang dijalankan dalam penelitian ini juga untuk menguji teori efisiensi pasar.

Studi ini menunjukkan bahwa selama periode pengamatan tidak ada adanya abnormal return, yang menunjukkan bahwa pasar secara langsung menyerap informasi baru yang relevan dan tercermin dalam harga saham, dengan demikian terjadi efisiensi pasar.

Implikasi pengambilan keputusan investor mengacu pada hasil penelitian ini, tidak akan ada pengembalian yang optimal jika mereka menerapkan strategi investasi aktif selama periode ini.

Jadi, dalam situasi efisiensi pasar yang sangat kuat ini, lebih baik bagi investor untuk tidak menerapkan strategi investasi aktif.
\end{abstract}

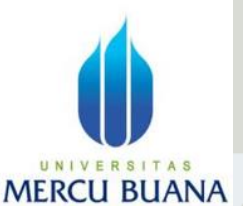

Jurnal Perilaku Dan Strategi bisnis

Vol.6 No.1, 2018

Hal. 9 - 20

Kata kunci; Suku Bunga BI, Efisiensi Pasar, Strategi Investasi.

\section{ABSTRACT}

Stagnation of BI Rate during year 2015 on 7.5\% level, causing a profit growth deceleration and stock price compulsion in banking sector. BI rate and BI 7-Day Repo Rate policy announcement on April 21st 2016 is a new relevant information for banking sector in Indonesia. Because both are as an interest rate reference for determining deposit and landing interest rate, which directly related to banking sector profit and expenses. 
This study verify an abnormal return existence during the announcement, in order to observe the market ability to directly absorb the relevant information and reflected in the stock price of the banking sector. The procedures which run in this study is also to test the market efficiency theory in the semi strong form.

This study indicate that during the observation period there is no existence of abnormal return, which is show that the market are directly absorb the new relevant information and reflected it in the stock prices. Thus the market indicate as semi strong efficient.

Investor decision making implication refer to this study result is there will not be an optimal return for them if they applied an active investment strategy during this period.

So, in this semi strong market efficiency situation, it is better for the investor not to apply the active investment strategy.

Keyword: BI rate, semi strong market efficiency, investment strategy

\section{PENDAHULUAN}

Industri perbankan memiliki peran yang strategis dalam perekonomian Indonesia. Perannya sebagai lembaga perantara antara pihak yang memiliki kelebihan dana dan pihak yang memerlukan dana menjadikan perbankan mampu menggerakkan pertumbuhan ekonomi sebuah negara. Industri perbankan yang produktivitas dan pertumbuhannya ditentukan oleh penetapan suku bunga yang diberlakukan sangat tergantung dari penetapan BI rate sebagai suku bunga acuan yang ditetapkan oleh Bank Indonesia.

Sepanjang tahun 2015 BI rate hanya mengalami penurunan 25 basis poindari 7,75\% menjadi 7,5\%, hal ini dilatarbelakangi oleh meningkatnya ketidakpastian di pasar keuangan global dan regional sebagai akibat ketidakpastian kenaikan Fed-Fund Rate (FFR) yaitu suku bunga acuan Amerika serikat yg ditentukan oleh bank sentral Amerika. Hal ini juga menyebabkan perlambatan pertumbuhan ekonomi di Indonesia, dari yang diharapkan sebelumnya $5,7 \%$ menjadi hanya 4,7\% selama tahun 2015. Pada industri perbankan hal ini mengakibatkan meningkatnya rasio non-performing loan yang berakibat langsung pada perlambatan pertumbuhan laba (bisnis.com). Perlambatan tersebut ditunjukkan oleh penurunan indeks saham perbankan sebesar 2,48\% sejak awal tahun hingga akhir tahun 2015. Penurunan indeks ini merupakan cerminan penurunan nilai saham perbankan yang ada di Bursa Efek Indonesia.

Pada tahun 2016 Bank Indonesia memutuskan untuk menurunkan BI rate secara bertahap sebesar 25 basis poin selama 3 bulan pertama diawal tahun. Tanggal terakhir penurunan BI rate menjadi 6,75\% adalah pada tanggal 17 Maret tahun 2016. Penurunan ini cukup signifikan jika dibandingkan dengan stagnasi nilai BI rate tahun sebelumnya sebesar 7,5\%. Hal ini dilatarbelakangi oleh meningkatkan kepastian ekonomi global setelah naiknya suku bunga acuan Amerika pada pertengahan desember tahun 2015, perbaikan pertumbuhan ekonomi secara signifikan, dan penguatan rupiah.(www.bi.go.id). Pada bulan ke-empat tahun 2016 BI memutuskan tidak melakukan penurunan BI rate, yaitu tetap berada pada level 6,75\%. Pada hari yang sama tanggal 21 April 2016, BI memperkenalkan BI 7-days (reverse) REPO rate yang akan berlaku efektif pada tanggal 19 Agustus 2016. Hal ini dilakukan agar suku bunga kebijakan dapat secara cepat memengaruhi pasar uang, perbankan dan sektor riil. Instrumen BI 7-Day Repo Rate sebagai acuan yang baru memiliki hubungan yang lebih kuat ke suku bunga pasar uang, sifatnya transaksional atau diperdagangkan di pasar, dan mendorong pendalaman pasar keuangan. Pada masa transisi, BI Rate akan tetap digunakan sebagai acuan bersama dengan BI Repo Rate 7 Hari. (www.bi.go.id).

Penetapan BI rate dan kebijakan Instrumen BI 7-Day Repo Rate sebagai acuan yang baru pada tanggal 21 April tahun 2016 ini merupakan informasi baru yang seharusnya menimbulkan reaksi positif pada perdagangan saham perbankan di Bursa Efek 
Indonesia, setelah sebelumnya Indeks sektor perbankan mengalami tekanan. Peristiwa ini menunjukkan optimisme pertumbuhan ekonomi yang lebih tinggi dari tahun sebelumnya. Pada dasarnya secara teoritis perubahan tingkat bunga berpengaruh negatif terhadap harga saham perusahaan. Jika tingkat bunga rendah, maka harga saham akan mengalami kenaikan sebagai akibat dari tingginya minat investor terhadap saham mengalihkan investasinya dari instrumen investasi yang lain. Hal ini akan mengakibatkan kenaikan pada harga saham sehingga harga saham akan mengalami kenaikan. Penelitian mengenai pengaruh negatif suku bunga yang diproxy-kan dengan BI rate oleh Rohmanda et all (2014) berpengaruh signifikan pada indeks harga saham sektor keuangan yang merupakan salah satu sektor dalam penelitian tersebut. Oleh karena itu penetapan BI rate dan kebijakan Instrumen BI 7-Day Repo Rate sebagai acuan yang baru pada tanggal 21 April tahun 2016 ini bisa dijadikan sebagai dasar pengambilan keputusan oleh investor untuk menjual, menahan maupun membeli saham perbankan di pasar modal.

Pola harga yang sekuritas di bursa saham disebutkan mengikuti pola random walk, karena perubahan-perubahan dalam nilainya adalah bersifat independen. Apabila hargaharga selalu mencerminkan semua informasi yang relevan, maka harga-harga tersebut baru berubah jika ada informasi yang baru muncul. (Husnan, 2009;263). Penetapan BI rate dan kebijakan Instrumen BI 7-Day Repo Rate sebagai acuan yang baru pada tanggal 21 April tahun 2016 ini merupakan informasi baru yang akan berdampak terhadap perubahan harga keseimbangan baru. Harga keseimbangan ini akan tetap bertahan hingga informasi baru datang dan kembali terjadi penyesuaian harga keseimbangan baru. Jika pasar bereaksi dengan cepat dan akurat untuk mencapai harga keseimbangan baru yang sepenuhnya mencerminkan informasi yang tersedia, maka kondisi pasar seperti ini dikatakan sebagai pasar yang efisien (Jogiyanto;2014).

Pasar yang efisien akan memberikan dampak pada harga sekuritas menjadi wajar sehingga tidak ada investor yang dapat menggunakan informasi yang tersedia untuk memperoleh keuntungan tidak normal (abnormal return) diatas kerugian investor lain. Sedangkan pada pasar yang kurang efisien harga sekuritasnya akan kurang bisa mencerminkan semua informasi yang ada, atau terdapat lag dalam proses penyesuaian harga, sehingga terbuka celah bagi investor untuk memperoleh keuntungan tidak normal (abnormal return) dengan memanfaatkan situasi lag tersebut. Fama (1970) mengklasifikasikan informasi menjadi tiga tipe, yang kemudian ditranformasikan menjadi tiga tingkatan untuk menyatakan efisiensi pasar modal. Pertama, adalah keadaaan dimana harga-harga mencerminkan semua informasi yang ada pada catatan

harga di waktu yang lalu. Dalam keadaan seperti ini para pemodal tidak akan memperoleh tingkat keuntungan di atas normal dengan menggunakan trading rules yang berdasarkan atas informasi harga yang lalu. Keadaan ini disebut sebagai bentuk efisiensi yang lemah (weak form efficiency). Kedua, keadaan dimana harga-harga bukan hanya mencerminkan harga di waktu yang lalu, tapi semua infomasi yang dipublikasikan. Keadaan ini disebut dengan bentuk efisiensi setengah kuat (semi strong). Dengan kata lain, para pemodal tidak bisa memperoleh tingkat keuntungan diatas normal dengan memanfaatkan public information. Ketiga, adalah bentuk efisiensi yang kuat (strong form) dimana harga tidak hanya mencerminkan semua informasi yang dipublikasikan, tapi juga informasi yang bisa diperoleh dari analisa fundamental tentang perusahaan dan perekonomian. Dalam keadaan seperti ini pasar modal akan seperti rumah lelang yang ideal, dimana harga selalu wajar dan tidak ada investor yang mampu memperoleh perkiraan yang lebih baik tentang harga saham (Husnan,2009;265). Menurut Karyadi (2012) pada bentuk semi-kuat hipotesis pasar efisien menguji informasi termasuk informasi yang tersedia bagi publik, seberapa cepat harga-harga sekuritas merefleksikan pengumuman informasi publik.

Tidak semua praktisi menerima konsep mengenai pasar efisien ini, dengan asumsi pasar 
inefisien, mereka bisa memanfaatkan inefisiensi pasar tersebut untuk mendapatkan keuntungan tidak normal (abnormal return). Implikasinya adalah investor yang percaya bahwa pasar dalam kondisi yang tidak efisien akan menerapkan strategi perdagangan aktif. Investor tersebut akan secara aktif melakukan perdagangan di pasar agar bisa mendapatkan tingkat keuntungan (return) yang lebih besar dibandingkan dengan return pasar. Di lain pihak bagi investor yang percaya pasar dalam kondisi efisien, akan cenderung menerapkan strategi perdagangan pasif, dengan membentuk portofolio yang bisa mereplikasi indeks pasar. Investor seperti ini percaya bahwa tidak ada satu investor pun yang dapat memperoleh abnormal return(Tandelilin,2009:129).

Peristiwa pengumuman Penetapan BI rate dan kebijakan Instrumen BI 7-Day Repo Rate sebagai acuan yang barupada tanggal 21 April tahun 2016 ini merupakan informasi yang berkaitan erat dengan perdagangan saham-saham perbankan. Fama menunjukkan bahwa bukti paling jelas tentang efisiensi pasar berasal dari studi peristiwa (event studies), terutama studi peristiwa return harian. Hasil studi peristiwa menunjukkan bahwa rata-rata harga saham melakukan penyesuaian dengan cepat terhadap informasi spesifik perusahaan yaitu keputusan investasi, perubahan deviden, perubahan struktur modal dan transaksi pengendalian perusahaan.

Penelitian ini akan melakukan pengujian efisiensi pasar setengah kuat dengan dasar sumber informasi publik tentang penetapan BI rate dan kebijakan Instrumen BI 7-Day Repo Rate sebagai acuan yang baru pada tanggal 21 April tahun 2016, dan implikasinya terhadap pengambilan keputusan beli dan jual saham khususnya perbankan. Menurut konsep semikuat,investor tidak akan mampu untuk memperoleh abnormal returns dengan menggunakan strategi yang dibangun berdasarkan informasi yang tersedia dipublik. Dengan kata lain, analisis terhadap laporan keuangan tidak memberikan manfaat apa-apa. Berlawanan dengan pasar efisien bentuk lemah, pada pasar efisien bentuk semi-kuat ada banyak investor yang berfikir bahwa mereka dapat memperoleh keuntungan dengan melakukan pengamatan secara seksama terhadap informasi publik yang tersedia di pasar, khususnya informasi akuntansi. Untuk mengetahui reaksi pasar terhadap informasi tersebut dan implikasinya terhadap keputusan investasi investor, maka perlu dilakukan pengkajian mengenai perilaku pasar dalam menyikapi informasi yang berkaitan dengan sahamsaham perbankan tersebut. Berdasarkan latar belakang tersebut maka timbullah dua pertanyaan sebagai rumusan masalah dalam penelitian ini, yaitu "Apakah pasar bereaksi dengan cepat dan akurat untuk mencapai harga keseimbangan baru?" dan "Apakah terdapat lag dalam proses penyesuaian harga, sehingga terbuka celah bagi investor untuk memperoleh keuntungan tidak normal (abnormal return)?"

Oleh karena itu dalam penelitian ini akan dilakukan pengujian terhadap abnormal return yang bertujuan untuk mengetahui reaksi pasar terhadap pengumuman penetapan BI rate dan kebijakan Instrumen BI 7-Day Repo Rate sebagai acuan yang baru pada tanggal 21 April tahun 2016 pada saham-saham perbankan di Bursa Efek Indonesia dan implikasinya terhadap keputusan investasi investor.

\section{HIPOTESIS PENELITIAN}

Dalam penelitian ini akan dilakukan pengujian efisiensi pasar setengah kuat dan berdasarkan kerangka konsep diatas berikut hipotesis yang akan diuji:

H1 : Terdapat abnormal return 3 hari sebelum penetapan BI rate dan kebijakan Instrumen $B I$

7-Day Repo Rate sebagai acuan yang barupada tanggal 21 April tahun 2016.

Hipotesis pertama digunakan untuk mengetahui apakah terdapat kebocoran informasi sebelum terjadinya sebuah peristiwa penetapan BI rate dan kebijakan Instrumen BI 7-Day Repo Rate sebagai acuan yang barupada tanggal 21 April tahun 2016

H2 : Terdapat abnormal return pada hari pengumuman penetapan BI rate dan 
kebijakan

Instrumen BI 7-Day Repo Rate sebagai acuan yang barupada tanggal 21 April tahun 2016. Hipotesis kedua digunakan untuk mengetahui apakah reaksi pasar pada peristiwa penetapan BI rate dan kebijakan Instrumen BI 7-Day Repo Rate sebagai acuan yang barupada tanggal 21 April tahun 2016.

H3 : Terdapat abnormal return 3 hari setelah penetapan BI rate dan kebijakan Instrumen $B I$

7-Day Repo Rate sebagai acuan yang barupada tanggal 21 April tahun 2016.

Hipotesis ketiga digunakan untuk mengetahui apakah pasar bereaksi terhadap peristiwa penetapan BI rate dan kebijakan Instrumen BI 7-Day Repo Rate sebagai acuan yang barupada tanggal 21 April tahun 2016.

\section{IMPLIKASI PASAR MODAL YANG EFISIEN DAN STRATEGI INVESTASI}

Implikasi hipotesis pasar efisien terhadap investor yang berinvestasi di pasar modal bisa dilihat dari implikasinya terhadap investor yang menerapkan analisis teknikal dan analisis fundamental dalam penilaian dalam pemilihan saham. Bagi investor yang menerapkan analisis tehnikal mereka pada dasarnya percaya bahwa pergerakan harga saham di masa yang akan datang, bisa diprediksi dari data pergerakan harga saham di masa lampau. Dengan demikian investor yang menerapkan analisis teknikal akan bergantung pada informasi masa lalu (historis) tentang data harga saham dan volume perdagangan saham, untuk memperkirakan harga saham di masa yang akan datang. Dalam situasi seperti ini, jika hipotesis pasar efisien dalam bentuk lemah benar, maka tindakan investor yang melakukan analisis teknikal tidak akan memberi nilai tambah lagi bagi investor, karena harga saham yang terjadi sudah mencerminkan semua informasi pergerakan harga dan volume saham historis.

Implikasi hipotesis pasar efisien terhadap investor yang melakukan analisis fundamental adalah sebagai berikut. Analisis fundamental merupakan analisis saham yang dilakukan dengan mengestimasi nilai intrinsik saham berdasar informasi fundamental yang telah dipublikasikan perusahaan (seperti laporan keuangan, perubahan deviden dan lainnya) untuk menentukan keputusan menjual atau membeli saham. Dalam situasi seperti ini jika hipotesis pasar efisien bentuk setengah kuat adalah benar, dimana semua informasi fundamental yang dipublikasikan perusahaan sudah tercermin dalam harga pasar, maka tindakan investor yang melakukan analisis fundamental untuk memperoleh abnormal return juga sudah tidak bermanfaat lagi (Tandelilin, 2010:130).

Strategi Investasi aktif menurut Jones (2014:304) adalah strategi yang didesain untuk menghasilkan return lebih besar dengan melakukan perdagangan secara aktif. Asumsinya adalah investor yang melakukan hal ini mendapatkan keuntungan lebih besar dibandingkan dengan investor lainnya, seperti kemampuan analisis dan penilaian yang sangat baik, memperoleh informasi terbaik, dan mampu melakukan hal yang tidak mampu dilakukan oleh investor lainnya. Sebagian besar investor masih memilih strategi ini dalam pemilihan saham dan manjemennya, meskipun telah terdapat beberapa studi mengenai pasar efisien. Alasannya adalah keuntungan yang didapatkan sangat besar dan beberapa investor meyakini bahwa mereka mampu mendapatkan keuntungan yang besar meskipun investor lainnya tak mampu melakukannya.

Bertolak belakang dengan strategi aktif, investor yang menerapkan strategi pasif dalam investasinya, percaya bahwa harga pasar yang terjadi adalah harga yang menceminkan nilai intrinsik saham tersebut. Sesuai dengan konsep pasar modal efisien yang menyebabkan tidak satupun investor bisa memperoleh abnormal return diatas pasar, sehingga investor tidak akan berusaha untuk secara aktif melakukan tindakan perdagangan saham yang bisa memberikan return abnormal. Strategi ini bisa juga diartikan sebagai tindakan investor dalam pemilihan dan manajemen investasinya hanya 
melakukan strategi beli dan simpan atau mereplikasi indeks dalam portofolio sahamnya (Tandelilin, 2010:200)

Penelitian ini akan menguji efisiensi pasar melalui pengamatan terhadap abnormal return selama periode peristiwa penetapan BI rate dan kebijakan Instrumen BI 7-Day Repo Rate sebagai acuan yang barupada tanggal 21 April tahun 2016, yang hasilnya dapat berimplikasi langsung terhadap strategi investasi yang digunakan oleh investor.

\section{TUJUAN DAN MANFAAT PENELITIAN}

\section{Tujuan Penelitian}

1. Mengidentifikasi abnormal return sebelum penetapan BI rate dan kebijakan Instrumen BI 7-Day Repo Rate sebagai acuan yang barupada tanggal 21 April tahun 2016, untuk mengetahui apakah terdapat kebocoran informasi sebelum terjadinya peristiwa yang menunjukan terdapatnya kemungkinan kebocoran informasi sebelum informasi baru muncul secara publik.

2. Mengidentifikasi abnormal returnpada haripenetapan BI rate dan kebijakan Instrumen BI 7-Day Repo Rate sebagai acuan yang barupada tanggal 21 April tahun 2016, untuk mengetahui bagaimana reaksi pasar pada saat peristiwa terjadi.

3. Mengidentifikasi abnormal return setelah penetapan BI rate dan kebijakan Instrumen $B I$ 7-Day Repo Rate sebagai acuan yang barupada tanggal 21 April tahun 2016, untuk mengetahui apakah pasar bereaksi setelah peristiwa terjadi.

4. Menguji efisiensi pasar bentuk setengah kuat ini diharapkan mampu menjelaskan bagaimana hasil penelitian ini berimplikasi langsung terhadap strategi investasi yang digunakan oleh investor.

\section{MANFAAT PENELITIAN}

Penelitian reaksi saham terhadap penetapan BI rate dan kebijakan Instrumen BI 7-Day Repo Rate sebagai acuan yang baru pada tanggal 21 April tahun 2016 diharapkan mampu memberi manfaat bagi akademisi tentang pengujian hipotesis pasar efisien bentuk setengah kuat, dengan dasar sumber informasi publik dan mampu menunjukkan bagaimana bentuk efisiensi pasar modal Indonesia, khususnya pada sektor perbankan. Manfaat penelitian ini juga diharapkan bermanfaat bagi pengambil keputusan, khususnya setor perbankan dalam perhitungan efisiensi beban bunga dan prospek keuntungan yang akan datang. Bagi investor hasil penelitian ini dapat memberikan perpektif tambahan kepada investor dalam pengambilan keputusan penjualan dan pembelian saham perbankan.

\section{METODE PENELITIAN}

\section{Rancangan Penelitian}

Penelitian ini akan menguji efisiensi pasar melalui penyerapan informasi baru berupa penetapan BI rate dan kebijakan Instrumen BI 7-Day Repo Rate sebagai acuan yang baru pada tanggal 21 April tahun 2016, melalui penghitungan abnormal return. Berikut formulasi perhitungan abnormal returnyang akan dipergunakan:

ARit $=$ Rit $-E[R i t]$

Periode yang digunakan adalah selama 7 hari, yaitu 3 hari sebelum terjadinya, 1 hari peristiwa tanggal 21 April 2016, dan 3 hari setelah peristiwa. Objek penelitiannya adalah seluruh saham perbankan yang terdaftar di Bursa Efek Indonesia selama periode peristiwa.

\section{Lokasi Penelitian}

Lokasi penelitian ini adalah di Bursa Efek Indonesia.

\section{Identifikasi dan Definisi Operasional Variabel}

1. Abnormal return adalah selisih antara actual return dengan expected return sebagai variabel yang diamati dalam penelitian ini untuk mengetahui efektifitas penyerapan 
informasi di Bursa efek Indonesia, dan pengujian efisiensi pasar akibat penetapan BI rate dan kebijakan Instrumen BI 7-Day Repo Rate sebagai acuan yang barupada tanggal 21 April tahun 2016.

2. Actual Return adalah return yang terjadi pada waktu ke-t yang merupakan selisih harga sekarang relatif terhadap harga sebelumnya, yang dapat diukur dengan rumus:

$$
R_{i t}=\frac{P i_{t}-P i}{P i_{t-1}} t-1
$$

3. Expected Return adalah return yang dapat diestimasi menggunakan beberapa model, salah satunya adalah market model. Pengunaan model ini dari ketiga model yang ada didasarkan pada asumsi bahwa dengan mengestimasi return yang diharapkan dari data historis, maka akan diperoleh ekspektasi yang lebih baik dibandingkan hanya dengan mendasarkan nilai ekspektasi pada indeks pasarnya saja. Perhitungan model ekspektansi ini menggunakan persamaan berikut ini:

ARit $=$ Rit $-[\cdot i+\cdot I \cdot R m t+e i t]$

Perhitungan expected return ini dalam persamaannya terdapat return pasar yang merupakan return pasar yang terjadi pada waktu ke-t yang merupakan selisih indeks harga saham sekarang relatif terhadap indeks harga saham sebelumnya, dapat dihitung dengan rusmus sebagai berikut:

$$
R m t=\frac{I m t-I m t-1}{m t-1}
$$

\section{Jenis dan Sumber Data}

Jenis data yang digunakan adalah data sekunder dari Indonesian Capital Market Directory berupa data harga saham perusahaan perbankan dan Indeks Harga Saham Gabungan, selama periode pengamatan. Bersumber dari web site resmi bursa efek Indonesia, www.bei.co.id

\section{Teknik Sampling}

Sampel penelitian ini adalah sama dengan populasinya. Populasinya adalah seluruh perusahaan perbankan di Bursa Efek Indonesia. Jumlah populasi perusahaan perbankan pada tahun 2016 adalah sebanyak 43 perusahaan. Penelitian ini menggunakan metode sensus, sehingga jumlah sampel dalam penelitian ini adalah 43 perusahaan perbankan di Indonesia.

\section{Metode Pengumpulan Data}

Metode pengumpulan data yang digunakan adalah metode observasi pada Indonesian Capital Market Directory berupa data harga saham perusahaan perbankan dan Indeks Harga Saham Gabungan.

\section{Teknik Analisis Data}

Pengujian dalam penelitian ini merupakan pengujian terhadap seberapa cepat suatu informasi diserap oleh pasar dapat digunakan untuk menguji efisiensi pasar bentuk setengah kuat (semi strong). Pasar dikatakan efisien secara setengah kuat jika investor bereaksi dengan cepat untuk menyerap abnormal return untuk menuju ke harga keseimbangan baru. Sebaliknya jika investor menyerap abnormal return dengan lambat maka pasar dikatakan tidak efisien bentuk setengah kuat. Melalui perhitungan abnormal returnyang diawali dengan perhitungan actual return dan expected return selama periode jendela 18 April sampai 21 April 2016, maka dapat ditentukan apakah pasar efisien dalam bentuk setengah kuat atau tidak dengan menguji signifikansi perbedaan rata-rata abnormal return selama periode pengamatan dengan uji beda. Software yang digunakan dalam 
pengolahan data adalah SPSS 15.

\section{HASIL DAN PEMBAHASAN \\ Gambaran Umum Perusahaan Perbankan di Bursa Efek Indonesia}

Perusahaan perbankan merupakan sektor ketiga di Bursa Efek Indonesia yaitu sektor Jasa. Sektor jasa terdiri dari 4 sektor salah satunya adalah sektor Keuangan dengan kode 8 (delapan) dan bank merupakan subsektor dari sektor keuangan dengan kode 81 (delapan puluh satu). Subsektor Bank terdiri dari 42 perusahaan.

\section{Statistik Deskriptif}

Tabel 1. Statistik Deskriptif Sampel periode pengamatan

\begin{tabular}{lcccc}
\hline & & & & Std. Error \\
& $N$ & Mean & Std. Deviation & \\
\hline Hmin3 & 42 & -.0246643 & .13185536 & .02034572 \\
Hmin2 & 42 & -.0188048 & .12604677 & .01944944 \\
Hmin1 & 42 & -.0196810 & .12710376 & .01961254 \\
H0 & 42 & -.0109048 & .09021817 & .01392097 \\
Hplus1 & 42 & -.0167262 & .10813193 & .01668512 \\
Hplus2 & 42 & -.0225524 & .14256940 & .02199894 \\
Hplus3 & 42 & -.0168548 & .13503517 & .02083638
\end{tabular}

\section{Data: diolah,2016}

Output statistik pada tabel diatas menunjukkan bahwa rata-rata abnormal return pada 3 hari sebelum penetapan BI rate dan kebijakan Instrumen BI 7-Day Repo Rate sebagai acuan yang baru pada tanggal 21 April tahun 2016 sebesar - 0,246643 dengan rata-rata penyimpangan abnormal return dari semua saham perbankan sebesar 0,13185536 . Hari berikutnya yaitu 2 hari sebelum penetapan BI rate dan kebijakan Instrumen BI 7-Day Repo Rate sebagai acuan yang baru pada tanggal 21 April tahun 2016 rata-rata abnormal return adalah sebesar $-0,0188048$ dengan rata-rata penyimpangan abnormal return dari semua saham perbankan sebesar 0,6084742. Satu hari terakhir sebelum sebelum penetapan BI rate dan kebijakan Instrumen BI 7- Day Repo Rate sebagai acuan yang baru pada tanggal 21 April tahun 2016, besarnya rata-rata abnormal return adalah sebesar 0,0196810 dengan rata-rata penyimpangan abnormal return dari semua saham perbankan sebesar 0,1961254.

Pada hari penetapan BI rate dan kebijakan Instrumen BI 7-Day Repo Rate sebagai acuan yang baru pada tanggal 21 April tahun 2016 rata-rata abnormal return adalah sebesar 0,109048 dengan rata-rata penyimpangan abnormal return saham perbankan sebesar $0,1392097$.

Berikutnya pada 1 hari pertama setelah sebelum penetapan BI rate dan kebijakan Instrumen BI 7-Day Repo Rate sebagai acuan yang baru pada tanggal 21 April tahun 2016, besarnya rata-rata abnormal return adalah sebesar 0,0167262 dengan rata-rata penyimpangan abnormal return dari semua saham perbankan sebesar 0,01668512. Pada hari kedua setelah penetapan BI rate dan kebijakan Instrumen BI 7-Day Repo Rate sebagai acuan yang baru pada tanggal 21 April tahun 2016, besarnya rata-rata abnormal return adalah sebesar 0,0225524 dengan rata-rata penyimpangan abnormal return dari semua saham perbankan sebesar

0,02199894. Hari terakhir pengamatan yaitu 3 hari setelah penetapan BI rate dan kebijakan Instrumen BI 7-Day Repo Rate sebagai acuan yang baru pada tanggal 21 April tahun 2016, besarnya rata-rata abnormal abnormal return adalah sebesar 0,0168548 dengan rata-rata penyimpangan abnormal return dari semua saham perbankan sebesar 
0,2083638.

\section{Hasil Uji T untuk satu Sampel}

Tabel 2. Hasil Uji T untuk satu sampel

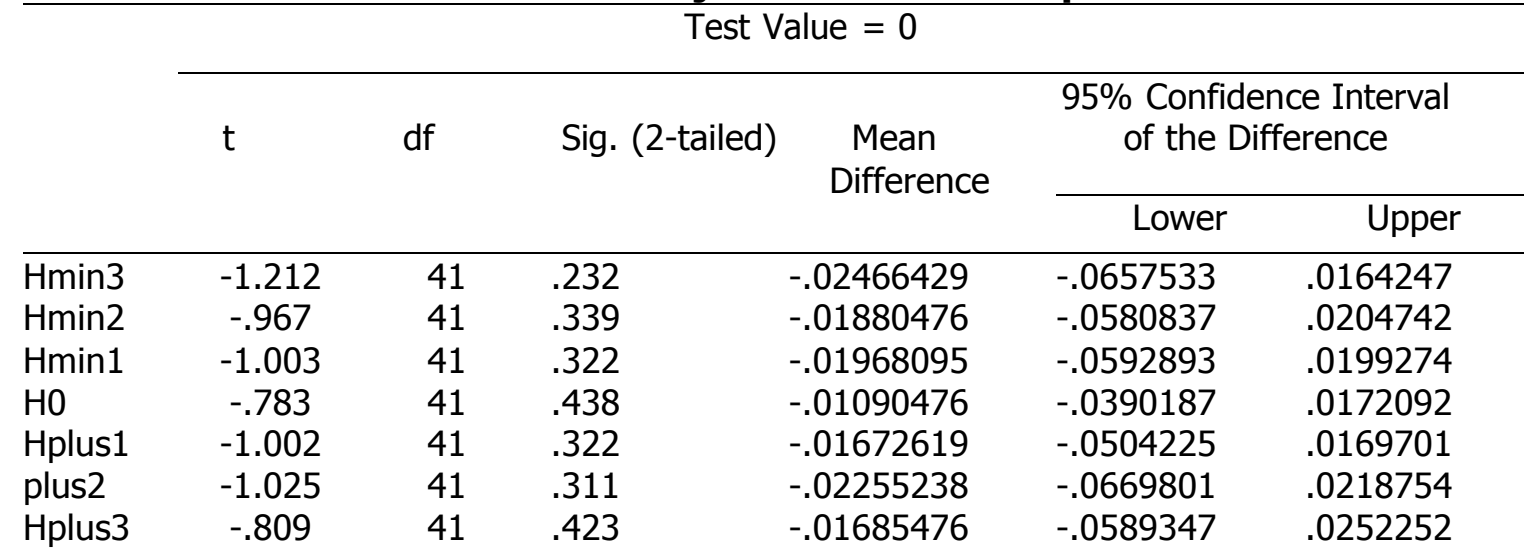

Data: diolah,2016

Hasil Uji T untuk satu sampel diatas menunjukkan beberapa hal yang berkaitan dengan hipotesis penelitian ini. Pertama, meskipun terdapat abnormal return pada hari ketiga, kedua dan sehari sebelum hari-H penetapan BI rate dan kebijakan Instrumen BI 7-Day Repo Rate sebagai acuan yang baru pada tanggal 21 April tahun 2016, namun rata-rata abnormal return tersebut tidak signifikan secara statistik. Hal ini ditunjukkan oleh tabel 5.3 dengan tingkat signifikansi (a)

$5 \%$, probabilitas dari ketiga hari sebelum hari-h lebih besar dari 0,05 yaitu 0,232 pada hari ketiga sebelum hari- $\mathrm{H}$, 0,339 pada hari kedua sebelum hari- $\mathrm{H}$, dan 0,322 sehari sebelum hari-H. Hasil yang menunjukkan probabilitas abnormal return dari 3 hari pengamatan sebelum hari $\mathrm{H}$ lebih tinggi dari tingkat signifikansi, hal ini menghasilkan penolakan terhadap hipotesis alternatif dan penerimaan hipotesis nol.

Kedua, hal yang sama juga tejadi pada hari- $\mathrm{H}$, tabel 5.3 diatas menunjukkan bahwa terdapat abnormal return negatif yang dapat dinyatakan sebagai abnormal return, dengan tingkat signifikansi $5 \%$, probabilitas 0,438 yang lebih besar dari 0,05 menunjukkan bahwa abnormal return tersebut secara statistik tidak signifikan. Hasil yang menunjukkan probabilitas abnormal return pada hari $\mathrm{H}$ lebih tinggi dari tingkat signifikansi, menghasilkan penolakan terhadap hipotesis alternatif dan penerimaan hipotesis nol.

Ketiga, setelah hari $\mathrm{H}$ tabel 5.3 menunjukkan kecenderungan yang sama, terdapat abnormal return pada hari pertama, kedua dan ketiga setelah penetapan BI rate dan kebijakan Instrumen BI 7-Day Repo Rate sebagai acuan yang baru pada tanggal 21 April tahun 2016, namun secara statistik tidak signifikan. Pada tabel 5.3, dengan tingkat signifikansi (a) 5\%, probabilitas dari ketiga hari sesudah hari-H lebih besar dari 0,05 yaitu 0,322 pada hari pertama sesudah hari- $\mathrm{H}, 0,311$ pada hari kedua setelah hari- $\mathrm{H}$, dan 0,432 pada hari ketiga setelah hari-H. Hasil yang menunjukkan probabilitas abnormal return dari 3 hari pengamatan setelah hari $\mathrm{H}$ lebih tinggi dari tingkat signifikansi, hal ini menghasilkan penolakan terhadap hipotesis alternatif dan penerimaan hipotesis nol.

\section{HASIL DAN PEMBAHASAN}

Jika dilihat dari statistik deskriptif pada tabel deskriptif sebelumnya, selama 7 hari pengamatan rata-rata abnormal return menunjukkan tingkat yang berbeda dengan nol. Hal ini menunjukkan bahwa terdapat abnormal return yang tidak normal. Namun hasil ini belum dapat menunjukkan apakah pasar secara efisien menyerap informasi tentang penetapan BI rate dan kebijakan Instrumen BI 7-Day Repo Rate sebagai acuan yang baru 
pada tanggal 21 April tahun

2016. Investor tidak bisa melakukan pengambilan keputusan investasinya hanya didasarkan pada statistik deskriptif ini saja.

Hasil penelitian berikutnya adalah ditolaknya hipotesis alternatif pertama yang diajukan yaitu terdapat abnormal return selama 3 hari sebelum penetapan BI rate dan kebijakan Instrumen BI 7-Day Repo Rate sebagai acuan yang barupada tanggal 21 April tahun 2016. Hipotesis ini bertujuan untuk menguji apakah terdapat kebocoran informasi mengenai pengalihan wewenang yang akan terjadi. Oleh karena hasil abnormal return selama 3 hari sebelum pengalihan wewenang tidak signifikan secara statistik, maka dapat disimpulkan bahwa tidak terjadi kebocoran informasi. Implikasi tidak terdapatnya kebocoran informasi pada investor adalah tidak terjadinya keputusan penjualan dan pembelian saham perbankan yang signifikan oleh investor.

Pada hari penetapan BI rate dan kebijakan Instrumen BI 7-Day Repo Rate sebagai acuan yang barupada tanggal 21 April tahun 2016, tidak terdapat juga hasil abnormal return yang signifikan secara statistik. Hal ini ditunjukkan oleh penolakan hipotesis alternatif yaitu terdapat abnormal return pada hari penetapan BI rate dan kebijakan Instrumen BI 7-Day Repo Rate sebagai acuan yang baru pada tanggal 21 April tahun 2016, yang mana hipotesis ini digunakan untuk melihat reaksi pasar terhadap penetapan tersebut. Hasil ini menunjukkan bahwa pasar tidak bereaksi secara berlebihan atau pasar bisa menyerap informasi yang bersangkutan dan informasi publik ini dengan cepat tercermin pada harga saham perbankan. Penyerapan informasi publik yang tercermin langsung pada harga saham perbankan menunjukkan pasar adalah pasar efisien setengah kuat. Dalam situasi seperti ini jika hipotesis pasar efisien bentuk setengah kuat adalah benar, dimana semua informasi fundamental yang dipublikasikan perusahaan sudah tercermin dalam harga pasar, maka tindakan investor yang melakukan analisis fundamental untuk memperoleh abnormal return juga sudah tidak bermanfaat lagi (Tandelilin,2009:130).

Jika pada hari pengalihan wewenang tidak terdapat abnormal return, pengamatan mengenai pasar efisien dapat dilakukan hingga tiga hari setelah pengalihan wewenang, karena reaksi pasar bisa saja tertunda. Sehingga hipotesis ketiga digunakan untuk mengetahui reaksi pasar setelah pengumuman. Hasil penelitian secara statistik menunjukkan penolakan terhadap hipotesis alternatif yang diajukan yaitu terdapat abnormal return selama tiga hari setelah penetapan BI rate dan kebijakan Instrumen BI 7-Day Repo Rate sebagai acuan yang baru pada tanggal 21 April tahun 2016. Hasil ini menunjukkan bahwa ketika tidak terdapat abnormal return, maka pasar mampu menyerap informasi yang relevan dengan cukup cepat, sehingga semua informasi publik yang ada segera tercermin pada seluruh harga saham perbankan. Penyerapan informasi publik yang tercermin langsung pada harga saham perbankan menunjukkan pasar adalah pasar efisien setengah kuat. Implikasi pada investor adalah pengambilan keputusan pembelian dan penjualan saham dari hasil analisis fundamental pada waktu yang bersangkutan tidak akan memberikan abnormal return yang optimal kepada investor.

Analisis ketiga hipotesis penelitian ini menunjukkan bahwa tidak terdapat abnormal return selama penetapan BI rate dan kebijakan Instrumen BI 7-Day Repo Rate sebagai acuan yang baru pada tanggal 21 April tahun 2016. Hal ini mengindikasikan bahwa selama periode pengamatan dengan adanya informasi publik berupa penetapan BI rate dan kebijakan Instrumen BI 7-Day Repo Rate sebagai acuan yang baru pada tanggal 21 April tahun 2016, tidak terdapat kebocoran informasi dan pasar dapat menyerap informasi tersebut dengan cepat sehingga tercermin segera pada harga saham perbankan di pasar. Jika demikian maka selama periode pengamatan pasar dapat dinyatakan efisien setengah kuat.

Implikasi hipotesis pasar efisien terhadap investor adalah sebagai berikut, jika investor melakukan analisis fundamental dengan mengestimasi nilai intrinsik saham berdasar informasi fundamental yang telah dipublikasikan perusahaan (seperti laporan keuangan, 
perubahan deviden dan lainnya) dan informasi publik (pengumuman peraturan baru) untuk menentukan keputusan menjual atau membeli saham dan jika hipotesis pasar efisien bentuk setengah kuat adalah benar, dimana semua informasi fundamental yang dipublikasikan perusahaan dan informasi public sudah tercermin dalam harga pasar, maka tindakan investor yang melakukan analisis fundamental untuk memperoleh abnormal return juga sudah tidak bermanfaat lagi (Tandelilin,2009:130). Begitu juga dengan melakukan transaksi penjualan dan pembelian saham selama periode bersangkutan tidak akan memberikan keuntungan yang optimal. Sehingga dalam situasi pasar efisien setengah kuat ini, investor sebaiknya tidak melakukan transaksi penjualan dan pembelian semata-mata untuk memperoleh keuntungan.

\section{KESIMPULAN}

1. Ketiga analisis hipotesis penelitian ini menunjukkan bahwa tidak terdapat abnormal return selama penetapan BI rate dan kebijakan Instrumen BI 7-Day Repo Rate sebagai acuan yang baru pada tanggal 21 April tahun 2016. Hal ini mengindikasikan bahwa selama periode pengamatan dengan adanya informasi publik berupa penetapan BI rate dan kebijakan Instrumen BI 7-Day Repo Rate sebagai acuan yang baru pada tanggal 21 April tahun 2016, tidak terdapat kebocoran informasi dan pasar dapat menyerap informasi tersebut dengan cepat sehingga tercermin segera pada harga saham perbankan di pasar. Jika demikian maka selama periode pengamatan pasar dapat dinyatakan efisien setengah kuat.

2. Investor yang melakukan analisis fundamental untuk menentukan keputusan menjual atau membeli saham untuk memperoleh keuntungan dan jika hipotesis pasar efisien bentuk setengah kuat adalah benar, dimana semua informasi fundamental yang dipublikasikan perusahaan dan informasi publik sudah tercermin dalam harga pasar, maka tindakan investor tersebut tidak bermanfaat. Begitu juga dengan melakukan transaksi penjualan dan pembelian saham selama periode bersangkutan tidak akan memberikan keuntungan yang optimal. Sehingga dalam situasi pasar efisien setengah kuat ini, investor sebaiknya tidak melakukan transaksi penjualan dan pembelian semata-mata untuk memperoleh keuntungan.

\section{SARAN}

1. Pengujian pasar efisien selajutnya sebaiknya menggunakan periode pengamatan yang lebih panjang, sehingga menghasilkan pengujian yang konsisten, meskipun dengan peristiwa atau informasi yang berbeda.

2. Investor sebaiknya tidak hanya mendasarkan keputusan pembelian dan penjualan sahamnya pada analisis tehnikal dan fundamental, tapi perlu juga dilakukan uji statistik untuk mendapatkan gambaran yang jelas mengenai abnormal return dalam usahanya memperoleh keuntungan.

\section{DAFTAR PUSTAKA}

Beaver,W.H. (2002) Perspective on recent capital market research, The Accounting Review, 77 (2), pp.453-474

Eduardus Tandelilin. 2009. Portofolio dan Investasi:Teori dan AplikasiI. Edisi: satu, Yogyakarta: Kanisius.

Fama, Eugene F. (1970). Efficient Capital Market: a review of theory and empirical work. Journal of Finance, 25(2):383-417. 
Foster,G. 1986. Financial Statement Analysis. 2nd Edition.Prentice Hall Englewood Cliffs. NewJersey.

Gumanti Ari T. dan Utami Sri E.(2002) Bentuk Pasar Efisien dan Pengujiannya. Jurnal Ekonomi Akuntansi, Fakultas Ekonomi-Universitas Kristen Petra.

Hanafi, M. (1997) Informasi laporan keuangan:studi kasus pada emiten BEJ. KELOLA.No.16-75-100.

Hartono,J, 2011. Teori Portofolio dan Investasi. Edisi: Delapan. Yogyakarta: BPFE.

Husnan Suad. 2005. Dasar-dasar teori portofolio dan Analisis Sekuritas. Edisi Empat.Yogyakarta : UPP AMP YKPN.

Jones, Charles P. (2014). Investment: Principal and concept. Jhon Wiley ans Son, Singapore $12^{\text {th }}$ Edition.

Karyadi, Hari (2012). Hipotesisi Pasar Efisien: Konsep, Anomali, dan riset Keperilakuan. Proceeeding dipublikasikan.

Khotahri,S.P. (2001) Capital market research in accounting. Journal of Accounting and Economics,31, hal 105-231.

Rhomanda et al. (2014). Pengaruh Kurs Rupiah, Inflasi dan BI rate terhadap Harga Saham: Studi pada Indeks Sektoral di BEI. Jurnal Administrasi Bisnis,Vol.13,No.1,Hal.1-10.

Samuelson, W.F. and SG, Mark (2003). Managerial Economics.4th edition, New York:Jhon Wiley And Son,Inc.

Scoot, W.R.2000. Financial Accounting Theory.2nd Edition, Prentice Hall International, Inc. Sudirman, Surya (2010).

bei.co.id bi.go.id 